\title{
Poetic Fiction as a Means of Choosing a Fairytale in Educational Process \\ for Different Aged Groups of Readers
}

\author{
Irina I. Grishina ${ }^{a}$ and Yuliya I. Vinokurova ${ }^{\mathrm{b} *}$ \\ ${ }^{a}$ Siberian Federal University \\ 79 Svobodny, Krasnoyarsk, 660041, Russia \\ ${ }^{b}$ MAEI Lyceum 7 \\ 15 Menzhinskogo, Krasnoyarsk, 660001, Russia
}

Received 03.09.2015, received in revised form 13.10.2015, accepted 02.11.2015

The research paper is concerned with the correct choice of magic texts based on a poetic fiction for getting useful information for future situations in life. The fairytale explains to the reader in simple and understandable language about the universe. It is no secret anymore that our ancestors laid in simple children's fairytales a much deeper meaning than it seems at first glance. In addition, fairy tales set a very strong bond between parents and children, especially if mom or dad is reading or telling a bedtime story, explain and comment on the story.

Keywords: fairytale, poetic fiction, miracle, educational process, children, adult people.

The article is written with the financial support of the European Commission within the Tempus IV programme (Project "Lifelong Language Learning University Centre Network for New Career Opportunities and Personal Development (UNICO)”, № 544283-TEMPUS-1-2013-1-ES-TEMPUSJPHES).

DOI: 10.17516/1997-1370-2015-8-11-2341-2347.

Research area: pedagogy.

The main feature of the fairytales is the revelation of the vital truth with uplifting or reducing the reality of the conventionally poetic fiction.

Vladimir Anikin

\section{Introduction}

The fairytale has ancient roots in human history and culture. Its stories are usually going to all the wisdom and experience of a people, in myths or parables not only fixing the underlying problem can be seen but also its solution. The word "tale", "miracle", "magic" has special value for people and pushes the boundaries of reality. In the fairy story most of the basic problems and life situations are encrypted, which are experienced by each person. People often closes on their own problems and not able to go beyond

(C) Siberian Federal University. All rights reserved

* Corresponding author E-mail address: kafiniaz@yandex.ru 
it, to comprehend the situation from different points of view. The fairytale due to its ageold wisdom penetrates deeply into the human beings unconsciousness and activates the human potential parts of personality that help to find their own way out of a problem state; a fairytale allows a person approach not in a directive way but gently, to the assessment of the situation, providing educational and therapeutic impact as on behavioral and as on a deep moral level.

Human being is not born independent, autonomous or responsible, as he is not born a personality. Human being becomes a personality in the process of growth and development in the society, or, according to psychologists, "psychological birth in the full sense is much later than biological birth." Growth and development is a natural move from dependency to independence, autonomy, and responsibility.

Using fairytales by caregiver, teacher, and psychologist to a certain growth stage must be constructed in such a way that the child, a specific age category, would be able to avoid stressful situations, disappointments. And here comes fairytale with its educational role for different aged readers and a special poetic fiction.

\section{What is Poetic Fiction?}

The main scientific controversies regarding the unique character of the tale is widely recognized and mentioned in the famous definition in "Concise Literary Encyclopedia": "The tale is one of the major genres of oral folk poetry, epic, prose mostly artwork of adventurous or domestic nature with the installation of the fiction" (Surkov, 1971, p. 880). Therefore, a traditional feature of fairy ales is "setting on fiction", and the relationship between people, values and other categories are not invented, but, as a rule, correspond to the historical reality of the socio-cultural practices. The main feature of fairytales was identified by V. G. Belinsky
(Belinskiy, 1983) and is that in reality neither performer nor listener believes.

For example, children believe in fairytales, in that reality that is described in fairytales, they believe in good fellows, the forces of darkness, etc. V. YA. Propp writes that "tale is based on a deliberate fiction, and this symptom is not secondary and is not accidental" (Propp, 1979, p. 47). The fiction substantially defines the entire poetics of the tale. Logically, fiction is installed correctly, as all other types of folk prose, containing fiction in one way or another (legend, fable, tale) is based on trying to convey the reality. The fairytales always tell something incredible, impossible in real life, but the fiction encompasses, as it is written by M. V. Lomonosov, the concept of "ordinary and natural" (Anikin, 1992, p. 4), so, the fiction is some truth, no wonder folk wisdom says: "In every lie there is a truth".

This idea is emphasized in reference books: "fairy tales - a variety of types of oral fiction (moralizing stories about animals, fairytales, adventurous stories, satirical jokes), hence the inconsistency in the definition of its specific genre characteristics. The tale is closed to the other types of oral prose: tale, saga, legend, from which the fairytale differs in that it takes the storyteller and the listeners perceived as a poetic fiction, as a game of fantasy. This basic principle of artistic technique of tales does not deprive it, however, the connection with reality, which determines from the ideological content, theme, language, character, motifs, images, parts of the narrative" (Surkov, 1971, p. 880-881). Here it should be mentioned the opposition of "the game of fantasy" - "connection with the reality". The result is a sustainable contrasting of fiction and reality, where the physical world is fictional (World of Action), and the world of moral (World of Value) is not changed (in the terms of A. Whitehead, 1990), that is why the fairytale can be attributed to the World of Values. 
Poetic fiction with regard to the fairytale is defined as overcoming the cognitive constraints of the mythological circle and therefore require certain and accurate reproduction of the structure and content of the myth in its prototypal forms. Such reproduction is typical not only for ritual texts such as incantations or spells and prayers. Every myth requires one interpretation circle, and from this point of view the spell is comparable to propaganda speeches, with the requirements of the putting down (writing) and reproducing statements made by political leaders, as well as to learn by heart vows and oaths. Poetic fiction is the overcoming of this circle by on the team or individual experience in the reality interpreting. As a result new experience is recorded in the internal experience of "ego" in such a way that semiotic space of alternative interpretations is released. Poetic fiction as a cognitive operation is well correlated with the act of thinking that $\mathrm{E}$. Bono calls "lateral" (Bono, 2005, p. 31), i.e., distant from the middle.

The commonality of fairytales and myth characteristics can be detected with the reference to the findings of the largest Russian specialist in classical mythology - A. F. Losev (Losev, 1991, 1996). He insisted on the inseparability of the ideal and the real in the myth, and as the result the specific element of wonder appeared in the myth. However, it is fiction as a kind of element of wonder - the essential distinctive characteristics of a fairytale. A. F. Losev, specially noted that "one should be a very poor idealist to try to tear a myth from the very midst of the historical process, and to preach a liberation dualism: the real life is by itself, but the myth is by itself too" (Losev, 1991, p. 256).

Here the question appears: if a myth produced by the power of the "fantasy", then how it can be a physical reality?

Myth distinguishes or can distinguish the truth from the apparent and fictitious from a real. Considering the possibility of identification of fairytales and myth, A. F. Losev notes that the mythic reality as it might seem at first glance, is a fabulous reality, unreal, and otherworldly.

However, for mythical consciousness the myth is nor fairytale entity neither just transcendental. This is the most real and the most animated, the most direct and even sensual entity (Kant, 1994, p. 27).

Mythical detachment is the detachment from the sense and idea of the day-by-day facts, but not from their factuality. Myth is actual exactly as all the real things; and if there is some difference between mythical reality and actual, and real reality, it does not mean that the first is weaker, less intense and massive, more fantastic and ethereal, but rather that it is stronger, often much more massive and intense, more realistic and material. Therefore, the only mythical form of detachment is the detachment from the meaning of things. "Things in myths" (Propp, 1979 , p. 38), remaining the same, take a very special sense, obey a very special idea that makes them detachment from, unrealistic, and giving a certain mystique, the miracle.

The carpet is an ordinary thing of everyday life; the Magic Carpet is one of the magical items found in the Russian author's fairytales. A carpet capable of flying through the air, taking the main characters to far-far-away and inaccessible spaces is not typical for Russian folklore and got into it, probably from the East under the influence of the Arabian nights where it encounters are nonexistent more often, as carpet - is required by prayer in the Muslim tradition (not by chance it is ascribed to magic functions). The difference between the ordinary and the fabulous thing is that they perform different functions. The place of "carpet" in the understanding of surrounding world is not in line with the concepts of "pattern", "wall" or "floor", but above - in "heaven." Invisible hat has magical properties: while wearing it a human being becomes invisible. The 
positive character can get the Invisible hat as a gift, win it, or exchange for anything else. Magic wand is a magical object from a fairytales. With the help of a Magic wand belonging, as a rule, to the magician or the fairy, the main character can create different wonders. At the time of being used the magic wand spilling sparks. Magic wand is not typical for Russian folklore, but it may be present in the form of a stick or latently implicit in the subtext, but the Magic wand "is perceived by Russian man as a typical attribute of Russian fairy tales" (Brilyova et. al, 2004, p. 184).

This transformation is a part of the semantic event, called "miracle". The mythical meaning of things does not prevent it to be a thing, rather, emphasizes its meaning (intension), endowing magical properties that can help the character in overcoming obstacles, to move it from one place to another.

A. F. Losev is right in his saying about that the myth should be examined by intensional, having independent value. It seems that A. F. Losev understands under the intensional the content of the concept, which was later formulated by M. V. Nikitin: "intensional - the central part (core) of the lexical meaning structure, including obligatory semantic features; the concept in his deductive-logical aspect, the meaning of the concept unlike of its volume" (Nikitin, 1988, p. 165). A. F. Losev wrote in his book: "most people do not want to understand that myth should be interpreted mythically, mythic content of the myth itself is quite deep and thin, quite rich and interesting, and that it has a value in itself, without any interpretations, and scientific and historical solving" (Losev, 1982, p. 291). It can also be claimed that the fairytale should also be explored, without separating its scientifically and analytically, but holistically, taking into account its internal, immanent fabulous specifics.

When the fairytale begins to be realized as the result of poetic fiction (i.e. the release of phenomenological space in which there is a place for individual creativity, where the poetic fiction is a cognitive tool of folklore), we can talk about the transition from the collective unconsciousness (myth) to an individually-phenomenological, embodied in the genre of fairytales as it is (Grishina, 2007).

The precedential "fairytales" reflecting the primitive rituals and mythological beliefs, contained a retelling of stories from the lives of the early period people, and, of course, as "storytellers" and the audience "believed in the authenticity of what fairytale narrated." "Fairytales" could arise as responses to actual events and passed down as "true story", gathering a mystery, but the events themselves were interpreted in the framework of the prevailing mythological representations of various spirits embodied in natural phenomena. In addition, the fairytale arose by transformation of the myths, the authenticity of which was not any doubt for some time and periods.

There are interesting observations and notes of N. I. Nikiforov about a very archaic Chukchi fairytales. Considering their primitive traits, N. I. Nikiforov doesn't even call them fairytales, but "pre-fairytales", thus emphasizing that it is a very ancient stage of the fairytales history. A Chukchi fairytale, says the author, "especially the "pre-fairytale", does not know of the poetics of European fairytales. As it rarely uses intonation "was" and, as a rule, the narrative begins with ex abrupto, in medias res," (Nikiforoff, 1928, p. 89-90).

An interesting phenomenon can be observed in fairytales of Madagascar. On Madagascar (at the end of the nineteenth century) was widespread belief in the characters' authenticity of fairytales and many people claimed to have seen them with their own eyes. The faith of this nation is reflected in the initial formulas of fairytales. Most of them contain the phrase "As the old folks say, and they are needed to believe", therefore, what the 
fairytale said, happened actually. Gradually, the worldview of the storyteller stops to exactly match the content of the fairytales, rather, with the range of views that fairytale contained. There is the appearance of special techniques with respect to the recording of the action in an indefinite past and unknown place, or a statement about the impossibility of repetition, i.e. about the exclusivity of talking about things, etc.

The fairytale, based on fiction is a type of folk consciousness creates the samples of the world of impossible and incredible transformations of events. Poetic fiction of fairytales connected with that fact that fairytale universe has a lot of plans and contains internal energy potential. The listener or reader is in the power of the perceived (fairytales) and by his wish he could come back from perceived events into his empirical existence.

\section{Fairytales in Educational Process for Different Aged Readers}

The relevance of the use and novelty of complex educational process by fairytale includes many methodological, pedagogical, linguistic, psychotherapeutic techniques in the context of a single fabulous and adapt them to the children's mentality to form a self-sufficient person, i.e. personality, who is confident in himself, relies on his strength and not dependent on other in their judgments and decisions.

For the preschool children fairytale is a conductor into the "adult" life, with its sometimes cruel moral laws; a fabulous events become the first "school of life", and the actions of the main characters - the measure of good and evil and guiding thread, leading to independence of decision-making. The fairytale teaches the child not only to understand the situation, but also to act in a certain way; thanks to the analysis and solution of fabulous situations the child receives intuitive criteria of choice and freedom of action, which is the main aim of the educational process for this concrete age. Children sooner or later face different kinds of problems, especially in our age of high-speed scientific and technological progress, and the sooner they learn the difficulties, learn to resist, to struggle with difficulties and find a way out, the easier and more productive they will be to solve the social problems of adult life.

The school children in the perception of magical works, first of all, pay attention to the main characters; they are interested in the appearance of the character, his actions and deeds. Pupils are experiencing all that happens to the main characters and their friends: violently happy for the victory of a positive character, a successful outcome, the triumph of good over evil. The fairytale has a psychophysical effect on children: causing joyful emotions, makes a move to develop it. Also contributes to the aesthetic development of children and they need to train the intellect. Favorite fairytale takes the child as a prisoner so that he does not separate himself from what is happening in it, plunging into it in detail presenting the events and the process of their participation in the represented.

Thus there is the education of such feelings as compassion, anger, surprise and so on. When reading fairytales the child develops and improves artistic and performance skills of speech. Many modern authors of fairy tales that are written for school age children, giving them the right attitude towards nature, the ability to take good care of living creatures; forming positive attitude to work, generate knowledge about adult work, about the organisation of work. All this contributes to the educational possibilities of teaching children skills. Mastering skills raises labour activity to a higher stage of development, allows the child to set and achieve a goal. The reading, the telling and retelling of fantastic works of the child-theschoolboy has a huge impact on the intellectual, 
mental, creative, psychological and psychophysical development, forms a moral and cultural side of a child student, conveys ideas about life, work and relationships in the society, thereby preparing the pupil for adult life.

In each case, there are sets of specific objectives and achieve specific goals, forming self-contained personality; it may be liberation, creation, correction, improvement, selffulfillment, self-esteem, ability to make action, to draw its own conclusions, judgments and choices.

Fabulous tasks provide an opportunity to examine a phenomenon with many views, also serve to finding multiple solutions of the inner problems and the only choice for the right path, according to child's opinion. Fabulous tasks can be invented or taken from special literature. Trying to find an answer to this fabulous task, the child speaks out his problem, at the same time finds the solution to it during the attempts of making laughing the audience. Thus, "the process of group decision and discussing makes the child's experience get richer and all this make the child be more adopted for the future situations" (Grishina, 2007), teacher, caregiver or psychologist are allowed to diagnose and to correct psychological problems in educational situations. Fabulous tasks in educational process must include the following points:

- the task is spoken out by the magic creature;

- fabulous tasks can be some kind of tests in fabulous games or adventures;

- the situation should not have a proper answer;

- the main characters' images should be of interest for children.

Different forms of telling fairytales allow us to solve the following tasks: identifying the most topical issues for the child; development of speech, memory, attention, imagination, ability to listen to each other and attach their thoughts to a common context; group cohesion. The method is based on the fact that the narrator either consciously puts the emphasis for the development of consciousness, or unconsciously reduces the accents in fabulous situations, which helps to understand the causes of their difficulties, to understand the problem.

\section{Conclusion}

So, in the fairytale the world of fiction is gesturing times (past, present and future), events, facts, dates, and creates a sense of the presence of a miracle. Mythical detachment is expressed by the transformation of ordinary things into an unusual, giving it the mystique, the wonder, gaining a special sense, a particular idea, value. This transformation makes things to have magical properties and qualities, which would be able to help the main characters in overcoming obstacles, difficulties, and misfortunes.

In the fairytale there is a different ontology, a different dimension of space-time existence, there is a description which is logically impossible, above-real, incredible time; different anthropology - the aging process and growth, life and death can be changed and reversed. A special "completeness" and multidimensionality of the fairytales is achieved by including the emotional, imaginative, intuitive beginnings and also a value starting. For listener or reader each of the possible virtual areas of the fairytale becomes open.

The fairytale in educational process is based on three principles - meaningfulness, the multiplicity and interaction with reality. The retelling and interpretation of fairytales allow the maximum release of creative beginning in the person, recognize their past experience, to enrich his perception, to gain new knowledge, learn to set goals, find the right treatment and to strive to realize goals thanks to their mental abilities and efforts. 


\title{
References
}

Anikin, V. P. Russian folklore tales. Moscow, Pressa, 1992. 560 p.

Belinskiy, V. G. About literature for children. Moscow, Det. lit., 1983. 430 p.

Bono, E. Lateral thinking. The textbook of creative thinking. Moscow, Popurri, 2005. 380 p.

Brilyova, I. S., Volskaya, N. P., Gudkov, D. B., Zakharenko, I. V. \& Krasnykh V. V. Russian cultural space: linguo-cultural dictionary. Moscow, Gnozis, 2004. 318 p.

Grishina, I. I. The functioning of a proper name in the crossword logic of the English author's fairytale. Abstract of the dissertation on a scientific degree. Irkutsk, 2007. 19 p.

Kant, I. Prolegomenon. Moscow, Leningrad, OGIZ, 1994. 377 p.

Losev, A. F. Sign. Symbol. Myth. Moscow, MSU, 1982. 479 p.

Losev, A. F. Philosophy. Mythology. Culture. Moscow, Politizdat, 1991. 525 p.

Nikitin, M. F. The fundamentals of linguistic theory of meaning. Moscow, $1988.168 \mathrm{p}$.

Nikiforoff, A. I. To the question of the morphological study of folktales. Moscow, $5^{\text {th }}$ state printing, 1928. $296 \mathrm{p}$.

Propp, V. Ya. The Folklore and the Reality. Moscow, Nauka, 1979. 327 p.

Surkov, A. A. Concise Literary Encyclopedia. Moscow, Sovet. encyc., 1971. V. VI. 1039 p.

Whitehead, A. N. Selected works on philosophy. Moscow, Progress, 1990. 719 p.

\section{Поэтический вымысел как один из критериев выбора сказки в образовательном процессе у разных возрастных групп читателей}

\author{
И.И. Гришина ${ }^{\mathrm{a}}$ Ю.И. Винокурова ${ }^{6}$ \\ ${ }^{a}$ Сибирский федеральный университет \\ Россия, 660041, Красноярск, пр. Свободный, 79 \\ ${ }^{6}$ Лицей №7 \\ Россия, 660001, Красноярск, ул. Менжинского, 15
}

\begin{abstract}
Данная статья посвящена правильному выбору волщебных текстов на основе поэтического вымысла для получения необходимой информации в будущем. Сказка объясняет читателю простым и понятным языком мироздание. Уже давно не секрет, что наши предки заложили в простые детские сказки гораздо более глубокий смысл, чем нам кажется на первый взгляд. Кроме того, сказки устанавливают очень прочную связь между родителями и детьми, особенно если мама или папа читают или рассказывают сказку на ночь, поясняют и комментируют сюжет.
\end{abstract}

Ключевые слова: сказка, поэтический вымысел, чудо, образовательный прочесс, дети, взросльее люди.

Статья написана при финансовой поддержке гранта программы ТЕМПУС IV Европейского Союза (проект «Создание сети университетских языковых иеетров для профессионального и личностного развития человека в рамках парадигмы «образование в течение всей жизни», № 544283-TEMPUS-1-2013-1-ES-TEMPUS-JPHES).

Научная специильность: 13.00.00 - педагогические науки. 